\title{
Correction: The economic dimension of migration: Kosovo from 2015 to 2020
}

\author{
Labinot Hajdari (1) \& Judita Krasniqi
}

Correction to: Humanities and Social Sciences Communications https://doi.org/10.1057/s41599-021-00923-6, published online 17 November 2021.

A correction has been made to the published article and PDF to ensure the following missing funding information is now included:

\section{Acknowledgements}

This publication is financed by the Polish National Agency for Academic Exchange as part of the "International Academic Partnerships" under decision no. PPI/APM/2018/1/00019/DEC/1.

In addition, the following ethics statements were also added for completeness:

\section{Ethical approval}

This article does not contain any studies with human participants performed by any of the authors.

\section{Informed consent}

This article does not contain any studies with human participants performed by any of the authors.

Published online: 30 November 2021

Open Access This article is licensed under a Creative Commons Attribution 4.0 International License, which permits use, sharing, adaptation, distribution and reproduction in any medium or format, as long as you give appropriate credit to the original author(s) and the source, provide a link to the Creative Commons license, and indicate if changes were made. The images or other third party material in this article are included in the article's Creative Commons license, unless indicated otherwise in a credit

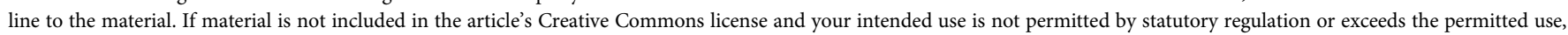
you will need to obtain permission directly from the copyright holder. To view a copy of this license, visit http://creativecommons.org/licenses/by/4.0/.

(C) The Author(s) 2021 